\title{
The Duty to Punish Past Abuses of Human Rights Put Into Context: The Case of Argentina
}

\author{
Carlos S. Nino $\dagger$
}

\section{INTRODUCTION}

We must be grateful to Diane Orentlicher for a thorough analysis of an extremely difficult issue.

However, I think that her theoretical discussion does not sufficiently account for the varied and often quite difficult realities successor governments must face. Orentlicher concentrates on questions of morals and law, and infers some conclusions about duty selectively to prosecute past violations of human rights. But the problem of inferring those conclusions is not so much related to moral or legal normative premises, but to factual ones which also condition the conclusions. I believe that Orentlicher leaves aside some relevant circumstances that successor governments may confront and that are crucial in deciding whether to prosecute human rights violations.

The aim of this Comment is to put Orentlicher's prescription into a factual context. ${ }^{1}$ I will share, as a case-study, some of the quite intricate aspects of the situation confronted by President Raúl Alfonsín's government in Argentina when conducting trials of human rights violations committed by both the previous government and leftist guerrillas. I intend to show that, once those circumstances are taken into account, the conclusions Orentlicher reaches must be highly qualified, at least in relation to Argentina's case.

I do not want to extend, without qualification, my conclusions to other cases. But knowing the complexities of situations like those in Uruguay and Chile, I doubt the beneficial effects of a general duty which does not take into account those complexities. ${ }^{2}$

$\dagger$ Advisor on constitutional issues to former President of Argentina Raúl Alfonsín; Professor of Law, University of Buenos Aires: Visiting Professor, Yale Law School.

1. Orentlicher, Settling Accounts: The Duty to Punish Human Rights Violations of a Prior Regime, 100 YALE L.J. 2537 (1991). In this article I will draw upon my first-hand knowledge and observations of the trials in Argentina. For a more detailed account, see O. GÓMEZ, EL DIARIO DEL JUICIO (1985) (microfilm on file at Yale Law School Library): Note, Human Rights: Conviction of Former Argentine Military Commanders for Human Rights Abuses Committed by Subordinates, 27 HARV. INT'L L.J. 688 (1986) (describing Argentine trials and convictions).

2. In the case of Uruguay, the amnesty law for human rights abuses committed under the previous military regime was ratified by a popular plebiscite. Could the population at large violate Orentlicher's proposed duty? In the case of Chile, there is an extremely delicate balance between the new and imperfect 
But let me first explain why I think that the moral and legal normative premises are not much of a problem for the conclusion Orentlicher reaches. Beginning with the moral dimension, the extent of the duty of a government selectively to prosecute past human rights abuses depends, of course, on the theory that underlies the justification of punishment. Only the theory of mandatory retribution - the view that every crime should be meted out by a proportional punishment, whatever the consequences of the policy-has implications different from the rest. In other places, ${ }^{3}$ I have described the irrationality and moral difficulty of this view of punishment. Though it is true that many people approach the issue of human rights violations with a strong retributive impulse, almost all who think momentarily about the issue are not prepared to defend a policy of punishing those abuses once it becomes clear that such a policy would probably provoke, by a causal chain, similar or even worse abuses. One might be a retributivist of the permissive variety, holding that a past wrong makes the criminal lose his immunity from punishment, but whether the state is morally obligated to punish him depends on the consequences of that punishment. Or, alternatively, one might think that those consequences are relevant to the very permissibility of punishment.

Still, in many views of punishment there is a strong element of deontologism in limiting punishment, whatever the consequences. In my own view, this deontological restriction on socially useful punishment derives from the requirement of the perpetrator's prior consent to undertake the liability of punishment, structurally analogous to the consent which constitutes a contract. This consent is evidenced by the fact that she acted voluntarily when committing the crime, conscious that liability would follow as a normative consequence of the act, regardless of her foresight of its actual enforcement.

Of course there are valuable consequences of punishment, for instance, to deter similar deeds by demonstrating that no group is above the law, or to consolidate a democracy which presupposes respect for the rule of law. But prosecutions may have some limit and must be counterbalanced with the aim of preserving the democratic system. This last caveat is all the more sensible once we realize that the preservation of the democratic system is a prerequisite of those very prosecutions and the loss of it is a necessary antecedent to massive violation of human rights. Mandatory retribution, which values punishment above all else, raises the issue of whether equality before the law is infringed when the need to protect valuable institutions, like democracy, leads to a selection of the agents who will be prosecuted for human rights abuses. The position that there is such an infringement of the requirement of equality presupposes mandatory retribution as the correct view of punishment.

democracy, and the remnants of the old regime. The legitimacy and the stability of the former is still based on some continuity with the latter, which enacted an amnesty law barring prosecution.

3. See C. Nino, THE ETHICS OF Human Rights (1991); Nino, A Consensual Theory of Punishment, 12 PHIL. \& PUB. AFF. 289 (1983). 
In order to clarify why only a conception of punishment based on mandatory retribution should be troubled by a selective policy, it is useful to resort to Dworkin's distinction between individual rights established by principles and collective goals imposed by policies. ${ }^{4}$ The recognition of rights implies the obligation to universalize that recognition to all similar situations, whereas collective goals create no such obligation. For example, if contraceptives are distributed to some people on the basis of the recognition of their right to control reproduction, they should be equally distributed to all others who are in the same relevant circumstances. If, instead, they are distributed to achieve some collective goal, such as containment in the growth of population, the distribution can take into account morally irrelevant circumstances such as probable fertility and can be stopped when the goal is achieved, even though some people are left without contraceptives.

Almost all views of punishment, with the exception of mandatory retribution, deny that anybody has a right that someone else be punished for a past crime. Punishing those who have relinquished their right not to be punished is not due to the recognition that the victims or their relatives have a right to that punishment. It is the consequence of a collective goal imposed by the policy of protecting human rights for the future. Therefore, nobody may claim to universalize that punishment to other similar cases when the goal of punishment will not be satisfied. Neither does government abstention from prosecution in this instance derive from the recognition of a right not to be punished, as it would be when that abstention is due to the recognition that the crime was justified. Consequently, other offenders cannot claim to be subject to the same treatment. This does not mean that the selection may be completely arbitrary or that it may proceed according to criteria which are generally proscribed, such as the race of the defendants. The selection must be done taking into account its use in satisfying the goals sought within the generally permissible criteria. Orentlicher seems to be generally in accord with me on this important point.

As a last preliminary matter, there remains some reference to the premises related to law, in this case to international law. I have argued elsewhere ${ }^{5}$ that normative propositions of law which justify actions and decisions derive from moral principles that legitimize certain authority, in this case international customs and conventions, and from propositions which describe enactments of the authority. Ultimately, a necessary criterion for the validity of any norm of positive law, including positive international law, is the willingness of the governing institutions, in this case states and international bodies, to enforce it. ${ }^{6}$ Orentlicher has not shown sufficiently that this is the case with the norm which supposedly establishes the duty of successor governments to selectively prosecute past violations of human rights.

\footnotetext{
4. See R. DWORKIN, TAKING RIGHTS SERIOUSLY 90-100 (1977).

5. See C. Nino, LA VALIDEZ DEL DeRECHO (1985).

6. See generally C. NINO, INTRODUCCIÓN AL ANÁLISIS DEL DERECHO (1980).
} 
Orentlicher's arguments are stronger if we interpret them as stating propositions about how international law should be reformed or developed rather than about what already exists. But such an interpretation returns us to the purely moral dimension with the need to assess quite complex causal chains. Indeed, the inclusion in international law of the duty to prosecute past crimes could itself cause some further negative consequences that must be taken into account in the moral assessment of the whole situation. This relates to one of Orentlicher's most interesting points, that the inclusion of this duty in international law will actually help governments in prosecuting human rights abuses. But any assessment of whether this would be so requires an examination of the complex factual setting of a particular case.

\section{A VIEW FROM THE TRENCHES}

Let me now describe quite succinctly the circumstances in which Alfonsín's government had to make decisions concerning the prosecution of human rights abuses committed by the previous military regime and leftist guerilla counterforces in the "dirty war against subversion." I hope that this narration will help us determine whether the government had a moral duty to prosecute those abuses and, if so, whether it discharged it. And we may further determine if Orentlicher's proposal to impose a legal duty under international law would have been helpful in discharging any existing moral duty.

By the end of 1982, Argentina was bursting with anger and hope. Amidst the economic crisis, the military regime had become completely discredited, due to (1) the loss of the Malvinas (Falkland Islands) War which unmasked the deceit it was prepared to impose upon the population, ${ }^{7}(2)$ the denunciations of acts of corruption, and (3) the horrendous stories of human denigration described in sensationalist detail in the weekly newspapers. The regime was collapsing and had to call for open and free elections. With time, two main candidates emerged, with opposite stances regarding the prosecution of past human rights violations. Mr. Italo Luder, a constitutional lawyer and Peronist Party member, argued that the abuses committed by the military could not be subject to trial due to the constitutional impossibility of retroactively abrogating the amnesty law ${ }^{8}$ enacted by the military regime.

His opponent, Mr. Raúl Alfonsín of the Radical Party, denounced the Peronist position as part of a pact with the military. Alfonsín promised to investigate human rights violations and to bring to trial both military chiefs who presumably gave the orders to abduct, torture, and kill "subversives," and the

7. For example, the regime claimed that it was winning the Malvinas War until the very end.

8. L.N. 22.294, promulgated Sept. 22, 1983 (granting amnesty to junta members). See infra notes $20-21$ and accompanying text. See generally Nino, Comment: The Human Rights Policy of the Argentina Coustitutional Government: A Reply (detailing legal obstacles to nullifying amnesty law) 11 YALE J. INT'L L. 217 (1985). 
officers who committed the worst excesses, regardless of their position of authority, together with the guerrilla leaders who also committed cruel human rights abuses. Alfonsin intended that the trials would exclude all those who committed crimes upon following orders.

To the surprise of many observers and leaders of the ousted regime, Alfonsin was elected President and assumed the position, forty days later, on December 10, 1983. Upon taking office, he announced a package of measures promoting human rights. He sent the Congress of Argentina drafts of bills, which they subsequently approved. The bills were designed to abrogate draconian criminal legislation enacted by the previous Peronist government and the military regime, ${ }^{9}$ to punish the crime of torture with the same penalty as murder, ${ }^{10}$ to ratify all the relevant international covenants dealing with human rights, ${ }^{11}$ to abrogate military jurisdiction for crimes committed in the future by men of the armed forces in connection with acts of service, ${ }^{12}$ and to eliminate other kinds of discrimination. ${ }^{13}$

To investigate past abuses, Alfonsín created the Comision Nacional Para la Desaparicion de Personas, CONADEP, a presidential commission made up of independent and respected citizens with full powers of investigation. ${ }^{14}$ Chaired by the famous writer Ernesto Sábato, this commission produced the well-known report, Nunca Más, ${ }^{15}$ within a year. The report contains a forceful and faithful narration of the horrible disappearances of people.

President Alfonsin thought it necessary to set limits on both the time and the scope of accountability to insure that the necessary exemplary trials and punishment of those mainly responsible for the worst deeds could be carried through to completion. Unlike Germany or Japan after the Second World War, Argentina had no invading army or domestic armed force to back the trials. And unlike the situation in Greece where some military factions did not oppose the trials, the army in Argentina was unified in its opposition. The armed forces which were responsible for the previous regime's "dirty war against subversion" still retained a monopoly on state coercion and were united in their opposition to the trials. Therefore, these limits were necessary to protect the only force backing the trial-the democratic system.

9. L.N. 23.077, promulgated Aug. 22, 1984.

10. L.N. 23.097, art.1, $\$ 1$, promulgated Oct. 24,1984 . If the torture victim dies, the torturer faces the same sentence as for murder. $l d$. art. $1, \$ 2$.

11. L.N. 23.054, promulgated Mar. 19, 1984 (ratifying American Convention on Human Rights).

12. L.N. 23.049, promulgated Feb. 14, 1984. See infra notes $25-32$ and accompanying text.

13. For a discussion of the other laws implemented, see Nino, supra note 8, at 219-21.

14. Decree No. 187/83, promulgated Dec. $15,1983$.

15. COMISIÓN NACIONAL SOBRE LA DESAPARICIÓN DE PERSONAS, NuNCA Más (1984). 
Contrary to Orentlicher's suggestion, ${ }^{16}$ it was politically impossible for the government to impose a short time limit for the trials beyond employing the comparatively open-ended procedures I shall describe below. Based on the strong public reaction to the "full stop" laws, ${ }^{17}$ which were enacted at a much less politically tense time, an ex ante attempt to draw a final deadline would have likely provoked an outburst from human rights groups, parties in the opposition, and national and international public opinion-an outburst so strong that it would have undermined the perceived legitimacy of the government. In addition, the resulting boomerang effect-the rush of hundreds to file criminal charges-would have unleashed a military reaction greater than the one later provoked by the boomerang effect of the "full stop" law. Furthermore, the scope of liability could not be directly established without violating the prohibition against ex post facto laws and bills of attainder. ${ }^{18}$

Because it was impossible to set limits on both the dates and the scope of liability directly, these had to be established through indirect mechanisms which at the same time were designed to surmount other legal obstacles. These obstacles were mainly three: the amnesty law enacted by the military, the military jurisdiction that was established for these crimes by the military code in force, and the regulation of the excuse of due obedience by the military code. ${ }^{19}$

The first obstacle, the amnesty law, affected the trials of both military men and guerrillas. Abrogation of the amnesty law would have been ineffectual because judges must apply the law most beneficial to the accused amongst all the applicable laws that were ever in force between the time of the crime and the completion of the punishment. ${ }^{20}$ Moreover, the retroactive modification of this article would have violated the mandate that defendants be prosecuted under the penal law existing at the time the offense was committed. ${ }^{21}$

The solution Congress adopted, on the initiative of the Executive, was not to abrogate but to declare null and void the amnesty law. ${ }^{22}$ This was possible because, under a new conception of the validity of laws enacted by authoritarian governments, ${ }^{23}$ the law was treated as a de facto imposed norm which, as such, did not carry the presumption of validity enjoyed by norms of democratic origin. Therefore, it would be valid only if its content were just. This solution contravened a long-standing practice of placing de facto laws on par with

16. Orentlicher emphasizes the example of Greece. See Orentlicher, supra note 1, at 2599-2600. But there the main trials were not for human rights abuses but for the coup d'etat carried out by the colonels. And in Greece the armed forces were much less cohesive than in Argentina. These factual differences explain the relative smoothness of the trials better than the legal technicalities that impress Orentlicher.

17. L.N. 23.492, infra note 41 .

18. Const. art. 18, (Argen.).

19. See Nino, supra note 8.

20. CóD. PEN. art. 2.

21. Const. art. 18 (Argen.).

22. L.N. 23.040, promulgated Dec. 27, 1983.

23. See C. Nino, LA VALIDEZ DEL DERECho (1985). 
constitutional ones; but it opened the gates for the trials of human rights violations.

The second legal obstacle was military jurisdiction. Because soldiers committed crimes as acts of military service and in military places, the prosecutions were legally under the jurisdiction of the military courts. ${ }^{24}$ Many people did not trust the impartiality of these military judges in assessing the acts of their colleagues. But modifying the jurisdiction law ex post facto would violate the prohibition against ex post facto loss of a court's jurisdiction over a case. ${ }^{25}$ On the other hand, though, the Constitucion prohibits the President from exerting judicial functions or imposing penalties. ${ }^{26}$ Employing this provision, the Alfonsín government argued that, because the military courts are administrative courts and form part of the executive branch, military jurisdiction would contravene the Constitucion. A compromise was reached whereby a first trial would be held before the military courts but with an automatic appeal before the federal court of appeals, where new evidence may be introduced. ${ }^{27}$ If the military court did not complete the trials within six months, then the federal court of appeals could either extend the military court's term or take over the cases. From the political perspective, the government allowed the military courts to retain preliminary jurisdiction under the misguided assumption that the military judges were prepared to subject some of their comrades to trial because of their desire to purify the military ranks of its tainted image. The government hoped that the military court would complete its work within the requisite time frame because military court procedures were more expedient and because it supposedly would select only a small set of accountable persons, filtering out the rest. The government thought that afterwards, in a rapid procession of appeals of rejected cases, the federal court could hear a few more cases erroneously rejected by the military court.

The third legal quandary was created by the military code's establishment of a defense of due obedience. ${ }^{28}$ When a soldier committed a crime under orders, the only person responsible for the crime was the officer who gave the

24. COD. JUSTICIA MLLTAR arts. 108-109. (Ediciones Libreria del Jurista 1985) (military courts have jurisdiction whenever crimes are committed either in military location or in connection with performance of acts of service).

25. "No inhabitant of the nation may be punished without previous trial based on an earlier law than the date of the offense, nor tried by special commissions, nor removed from the judges designated by the law [existing] before the date of the offense." CONST. art. 18, as translated in 1 CONST. OF THE THIRD WORLD (1991).

26. "In no case may the President of the Nation exercise judicial functions, assume jurisdiction over pending cases, or reopen those decided." CONST. art. 95, as translated in 1 CONST. OF THE THIRD WORLD (1991).

27. This procedure of automatic and plenary review parallels the appeals process from other administrative courts, guaranteeing the constitutionality of a trial by an administrative court. See, e.g., Fernandez Arias v. Paggio, 247 Fallos 646 (1960).

28. CóD. JUSTICIA MLITAR art. 514 (Ediciones Libreria del Jurista 1985) (when crime was committed in execution of order of service, superior who gave order will be sole responsible person, and subordinate will only be considered accomplice when he has exceeded in fulfillment of that order). 
order, unless the subordinate exceeded the limits of that order, in which case he could be punished only as an accomplice. ${ }^{29}$ Although this military code was useful in limiting the scope of persons to be tried, it had the undesirable effect, if literally interpreted, of reprieving too many mid-level officers who should be tried. Once again, this regulation could not be retroactively abrogated without violating the Constitucion. ${ }^{30}$

Fortunately, courts and scholars had interpreted this provision of the military code as presupposing the excuse of mistake as to the legitimacy of the order given. Taking into account the special circumstances lower officers faced, such as institutional pressures, threats, and propaganda, the draft Alfonsín sent to Congress established a revocable presumption that those who committed crimes under orders, and without decision-making capacity, had mistakenly relied on the legitimacy of the orders received. This phrasing allowed for a restriction on the responsibilities of all but those who gave the orders, those who received orders but who had a great deal of discretion about how to comply with them, or those who committed some of the extraordinarily brutal abuses of human rights which called for exemplary punishment. In the latter case, the very nature of the deed constituted evidence which permitted a judge to revoke the presumption that the agent had believed the orders were legitimate. With this normative interpretation, the draft sent to Congress tried to strike a balance between an outrageous literal interpretation, which would have established the immunity of all but the members of the Juntas, and an excessively harsh interpretation, which would have unfairly required each defendant to prove positively that he was led to believe that the order was legitimate.

But the draft was substantially altered before its enactment, ${ }^{31}$ leading to confusion rather than clarity. A senato ${ }^{32}$ from a small party generally allied with Peronism successfully proposed to amend the draft to restrict application of the presumption of mistake so that a broader group of soldiers would be exposed to the threat of prosecution. The presumption of mistake about the legitimacy of the orders now would not apply to abhorrent or atrocious acts. The clause of due obedience now did not define the limits of accountability and therefore did not eliminate the threat of prosecution for perhaps hundreds of officers, because, as both their friends and members of the human rights groups were keen to repeat, every crime committed in this context might be deemed "abhorrent and atrocious."

The government could not possibly produce a precise description of the most abhorrent violations of human rights without committing itself to conducting hundreds of trials. But neither could the government choose a closed

29. The penal code also provides a defense of due obedience. COD. PEN. art. 34(5) (those who acted in virtue of due obedience are not to be punished).

30. Const. art. 18 (Argen.).

31. L.N. 23.049, supra note 12.

32. E. Sapag from the province of Neuquen. 
list of well-known torturers and executors to be prosecuted because that would have been unconstitutional. Instead, the government sought to accomplish its goal of limiting the set of people under trial through both the filter of the military court's selection of cases (under federal court surveillance) and the clause of due obedience.

Apart from some ambiguous preliminary decisions, ${ }^{33}$ the military court would not go forward with the trial proceedings. Under heavy pressures from their comrades, the military judges allowed the established time of six months, plus an extension, to elapse. The Federal Court of Appeals of Buenos Aires assumed jurisdiction and conducted the trials of the members of the Juntas and of the commanders of the region of Buenos Aires. ${ }^{34}$ These famous trials were successfully carried out amidst great public attention and emotion. On the other hand, most of the federal courts of appeals of the interior of the country were extremely slow in taking over jurisdiction and going forward with their cases. Perhaps this was so because the interior court members were chosen with less care concerning their commitment to justice in these cases and their independence from the establishment forces of their provinces.

In the end, none of the limits that Alfonsin thought necessary for protecting the democratic system were closely followed. This failure was due to the democratic but uncoordinated participation of independent agents such as Congress and the Courts. As Alfonsín had feared, delays of months and years for the second series of prosecutions, especially after the success of the earlier trials, produced more and more unrest in the military rank and file. Hundreds of military men felt threatened by the prospect of prosecution. Some officers took advantage of the unrest. They attempted to rouse the troops by claiming that the trials were part of a plan to dissolve the armed forces and pointed for evidence to leftist groups who spoke as if the entire military, not just certain officers, were responsible for the genocide.

A direct attempt of coup d'etat seemed unlikely because of lack of public support. But the government feared that the military would refuse the courts' orders to attend the proceedings. The government could not avail itself of enough force to coerce an accused officer to present himself before the court. Such an admission of powerlessness would delegitimize the government and then make it vulnerable to an open or covert coup d'etat by creating a dangerous power vacuum.

The threat became more and more real by the end of 1986 . Finally, with much hesitation and internal division, the government decided to act. First, the

33. On the one hand, the military court indicted the members of the Juntas but, on the other hand, the court seemed to justify their deeds in those indictments.

34. See La Nación, Dec. 10, 1985, at 17 (judicially drafted synopsis of decision). See also Human Rights, supra note I (describing trials and convictions). These trials produced an enormous impact on public consciousness. It was the first time in the federal ambit that oral penal proceedings took place, thanks to a reform of the procedures established in the military code. 
minister of defense gave instructions to the military prosecutors both to speed up the remaining trials and to concentrate on prosecuting the officers outside the due obedience exception. But the Federal Court of Appeals of Buenos Aires reacted harshly ${ }^{35}$ and took over the pending military cases which were within its jurisdiction, thus making these instructions ineffectual.

Next, in December 1986, President Alfonsín sent to Congress a legislative proposal ${ }^{36}$ to establish a term of sixty days to indict military men involved in the "dirty war against subversion." This popularly termed "full stop" law was highly criticized both at home and abroad ${ }^{37}$ Despite the fact that the sixty-day time frame overlapped with the judicial recess of one month, this law had a boomerang effect of awakening the courts of the interior who were presumably unwilling to be responsible for the eternal impunity of some criminals. More than 450 people were indicted.

Because of this rejuvenation of the courts, the long feared military response materialized, creating a very real threat of further violence and bloodshed. During Easter week, 1987, some officers refused to obey judicial orders of detention. They holed up in a military garrison, protected by their fundamentalist comrades, the so-called "painted faces," who launched "Operation Dignity" to preserve the armed forces against the radical government and the accomplice generals.

The President could not obtain sufficient force to overcome the resistance. Alerted as to what was going on, millions of people gathered to support democracy in the Plaza de Mayo in front of the governmental house in Buenos Aries and in other towns of the interior. Alfonsín went by helicopter to the garrison to obtain the surrender of the rebels. After hours of tension, Alfonsin returned, announced that the rebels gave up and were under arrest, requested that all of the people return quietly to their homes, and wished them a "happy Easter".

Alfonsín declared later on TV, confirmed by his military attache, that the rebels displayed a humble attitude and regretted that they, who had fought in the war, were under permanent suspicion of being criminals. The President replied that he was obliged to respect the independence of the judiciary. However, he transmitted his hope that the Supreme Court would act expediently to define the limits of due obedience in pending decisions.

Despite the apparent happy ending of these dramatic days, the worst part was still to come. First, in the following days the government learned that other military officers were going to resist court citations. This challenge to the government's authority was only temporarily averted by the cooperation of the

35. Three of its members resigned. Afterwards, two of them withdrew their resignations, but one member left the court.

36. L.N. 23.492, promulgated Dec. 24, 1986.

37. See, e.g., Justice Diluted in Argentina, N.Y. Times, Feb. 25, 1987, at A26, col. 1. But see Nino, Speedy Trials for Argentina's Military?. N.Y. Times, March 6, 1987, at A30, col. 1 (letter to editor). 
Supreme Court, which asked for the court's files of those cases, thus effectively suspending the trials. Second, a psychological campaign, initiated by some sectors of the military front ${ }^{38}$ and followed by the Left, claimed that the government had negotiated an amnesty law with the military. "Happy Easter" and other expressions of Alfonsín's speech were incessantly repeated with an ironic twist. Third, the government came to realize that the Supreme Court refused to take the responsibility of defining the limits of due obedience.

The government became frantic. Heated discussions ensued in meetings between ministers, advisors, congressmen, and presumably the military, over the possible solutions: do nothing at all, propose to Congress an amnesty law, grant presidential pardons, introduce prosecutorial discretion, or define by law the scope of due obedience. All those cards were put on the table and one by one they were rejected. Doing nothing would lead to disaster. Granting amnesty would excuse too many officials since, according to the Constitución, it should be general, and according to the military code it would necessarily extend to the principals. ${ }^{39}$ Granting presidential pardons to people not yet convicted would be unconstitutional. ${ }^{40}$ And permitting prosecutorial discretion would contravene legal tradition and would put an undue burden on the shoulders of the attorney general.

In the end, the government adopted the last remedy. It proposed a law, adopted by Congress, ${ }^{41}$ which made the revokable presumption of due obedience henceforth irrevocable. The law defined which military ranks held decision-making capacities, and excluded the exception of atrocious and abhorrent acts for all other military ranks.

The campaign against this law was wild, both at home and abroad, resulting in enormous political costs for Alfonsín's government. Journalists and intellectuals of the countries whose socialist leaders had repeatedly advised Alfonsín to put an end to the trials subjected his government to extremely harsh criticisms. The human rights group Alfonsín co-foundea, designed to protect people from military repression during the trials, threatened to fire him. The Radical Party also bore the political cost of the law, as evinced by its poor performance in the parliamentary and provincial elections of September 1987.

However, the main benefit of the law began to materialize almost immediately. When the "painted faces" rebelled again, ${ }^{42}$ they were repressed by the bulk of the military, which now clearly expressed their support for democratic institutions. The fear of trial was no longer a strong cohesive element. Hence, during the last rebellion President Alfonsín was able to declare that he would

38. See J. Morales SOLÁ, Asalto a la Ilusión 161 (1990).

39. Const. art. 16 (Argen.).

40. CONST. art. 95 (Argen.).

41. L.N. 23.521, promulgated Juñ 4, 1987.

42. First, in January, 1988, in Monte Caseros and then in December of the same year in Villa Martelli. 
not limit the trials any further, and as a result he was acclaimed by both Houses of Congress.

But these successes of the government were ultimately clouded by the terrorist attempt to garrison La Tablada in January, 1989, and by the hyperinflation which exploded from February 1989, onward. This led to the Radical Party losing the presidential election of May 1989. Alfonsin resigned before the expiration of his term of office when he realized that only the newly elected government could contain the economic and social crisis.

As a result, the final page of this story about the trial for human rights abuses was written instead by the Peronist President Carlos Menem, who assumed control of the government in July of 1989. Menem granted presidential pardons to all those convicted or under trial for state and subversive acts of terrorism, for misconduct in the war, or for rebelling against democratic institutions. ${ }^{43}$ These pardons extended to even the main officers responsible for organizing the whole machinery of terror. ${ }^{44}$

The pardons of those most responsible did nothing to promote the goal of preserving human rights for the future. They were granted instead to reconcile different sectors of the "Argentine family," blurring the moral condemnation of the atrocities committed and treating the crimes as if they were the result of a mere feud between contending groups. This was qualitatively different than Alfonsín's measures for limiting the trials.

The formation of a social consciousness against human rights abuses depends more on the exposure of the atrocities and on the clear condemnation of them than on the number of people actually punished by them. Hence, one of the justifications for the measures undertaken by Alfonsín's government to limit the trials was to make possible the punishment of the main culprits. Since the pardon of those most responsible for both kinds of terrorism is deleterious to that consciousness, blanket pardons confirm the impression that the rule of law never applies to the powerful, creating incentives to act illegally and fostering disaffection in the country ${ }^{45}$ Because the highest conductors of the reign of terror during the 1970's were serving their sentences even while less powerful individuals were exempted from them, people realized that power is not immune from prosecution. This is no longer the case with the pardons granted by President Menem.

\footnotetext{
43. On December 3, 1990, these soldiers rebelled again and are now on trial once again.

44. The most notorious culprits for the massive human rights violations, such as Videla, Massera, Viola, Camps, Suarez Mason, and Firmenich, were all pardoned.

45. For a more detailed discussion, see C. NINO, LA FILOSOFf́a DE LA PRÁCTICA CONSTITUCIONAL ARGENTINA (forthcoming).
} 


\section{An Analysis of the Proposal in Light of Some Distinctive Fea- TURES OF THE ARGENTINE CONTEXT}

What I want to do in this section is to explore whether creating a duty under international law for a successor government selectively to prosecute violations of human rights committed during the previous regime would have contributed to overcoming each of the factors which made the prosecutions difficult for Argentina.

In this analysis I shall assume that a duty imposed by international law is enforced by some international organization or by other states. Enforcement could range from condemnation to measures such as economic isolation. This assumption, far-reaching as it is, shows the unlikelihood that Orentlicher's duty is presently recognized, at least strongly, in international law. Countries will sometimes ignore their crude interests in order to sanction foreign governments which actively violate human rights in extreme ways. But it would be excessively fanciful to imagine a situation in which any countries will sanction governments for giving a blind eye to abuses committed by previous regimes. Nevertheless, it is interesting to examine whether the existence of the duty would make enough of a difference that it would be worth struggling to develop international enforcement of international law.

Let us now look at some of the factors which I think made prosecutions difficult in Argentina and how they could have been affected by the duty which Orentlicher promotes.

\section{A. The Absence of Negotiations and Agreements}

Given the enormous transcendence that the outcome of the trials had for the institutional future of Argentina, one would certainly have assumed that a complex set of agreements developed ${ }^{46}$ between the different political parties controlling state power, between the government and the military, between the government and the various human rights groups, and even between the government and the judiciary. ${ }^{47}$ But this was not the case. There were scattered conversations, but no real and concrete negotiations and agreements. Thus, the different parties involved acted independently, without significant coordination. There were occasional small gestures of cooperation; but, as discussed above, this was not the case in most situations.

Perhaps the magnitude and closeness in time of the atrocities in Argentina spread a desire for retribution which foreclosed most possibilities for negotia-

46. Spain, Uruguay, and Chile all evinced this tendency.

47. One may take issue with the notion of making deals over the extent of trials. But, as explained above, absolute retribution without compromise is morally reprehensible as well as counter-productive when it causes further violations of human rights by provoking factions of the military. See supra text accompanying note 4. 
tion. Maybe the frequently mentioned political intransigence of the Argentine people prevented compromise. ${ }^{48}$ Certainly there were elements of distrust which made any negotiations difficult. The military thought that the government intended to promote the trial of hundreds or even thousands of troops, while the human rights groups thought that the secret intention of the government was to grant amnesty to all or most of the wrongdoers. If both groups could have believed that the government intended to promote the trials of, let us say, between thirty and sixty accused, they both would have been relieved of their fears. An agreement to that effect between all the parties concerned, including the judiciary, would have saved everyone costly tensions and frustrations.

The structure of interaction between the different Argentine actors was not appropriate for reaching a deal. In reading a recent book about the logic of collective interaction in the Spanish transition to democracy after Franco's destructive reign ${ }^{49} \mathrm{I}$ was struck by the fact that the process of negotiating and reaching agreement was helped by the circumstance in which three groups of comparable strength could pressure one another equally. The Francoists and the opposition led by the Socialists had the compromise proposed by the government as a second choice. And the government could threaten to align itself with either of the groups, forcing on the other its worst option.

But the different parties involved in the trials for human rights violations in Argentina were not equal in power and influence. The threatening power of the human rights groups was fairly weak, consisting initially in the power to move public opinion at home and abroad, and eventually only in provoking some international reaction. But, more importantly, those threats only affected the government by discrediting it and undermining its perceived legitimacy. Sectors of the military and their supporting groups stood to benefit from any of these threats carried out against the government.

Would the structure of collective action have been different if Orentlicher's proposal had materialized? The bargaining power of the government to carry out the trials would not have been strengthened by the prospect of international condemnation of the country for failing selectively to prosecute past human rights abuses. This international pressure would not have been seen by resilient sectors of the military as a threat to them. Perhaps the position of the groups defending human rights would have been stronger if it were backed by a norm of international law. But their strength would have been directed against the government and not against the resistant sectors of the military. The only group that would have gained power is the least appropriate beneficiary, the perpetrators. Extremist groups among the military would have welcomed the weakening of the government and its policies through the loss of legitimacy in society and the loss of international prestige.

48. There is even a party which prides itself on being called "intransigent".

49. See J. Colomer, La Manipulatión del PODER (1990). 
Perhaps the existence of a duty selectively to prosecute enforced by very harsh sanctions would have made a difference in the structure of collective action. ${ }^{50}$ The sanctions would have affected the population at large, creating enormous additional pressure on the resilient sectors of the military to overcome their resistance to face the trials. But, as I said before, the possibility of the world powers presently reacting so harshly against a government for failure selectively to prosecute the violations of a previous regime is a complete fantasy.

\section{B. The Breakdown of Common Discourse}

Bargaining did not prosper among the parties involved in the trials for human rights violations in Argentina. The other mode of communication, arguing with the aim of persuading, proved difficult when addressed to some sectors of the military.

With years of formal and informal education, many military men develop a world view significantly different from that of most citizens. Therefore, they develop modes of practical discourse quite disconnected and isolated from that employed by the rest of society. This mode of discourse reflects and reinforces their ideology of a supreme value, the flourishing of the National Being. This National Being does not evolve with the history of the country; its structure is not dependent on the Constitucion, which is seen as a mere instrument; nor is its will expressed through the democratic process. Thus, because this National Being has no empirical foundation, it is constantly threatened by enemies who are determined to destroy its identity by undermining its military strength, its religion, and its regime of property. The armed forces, as well as the Church and other "real" powers, are to be the natural defenders of that National Being, since they have a privileged epistemic access to its needs.

The "dirty war against subversion" was justified under this ideology, with supporting rhetoric. Many of the military defended the sacrifice of innocent individuals and the complete disrespect for the Constitución and for the rule of law as a necessary means for preserving the National Being.

Sometimes inconsistency emerged within this mode of discourse when military leaders did not justify their crimes but flatly denied them. At other times, accused military officers wavered between denial and justification. But overall, those military men involved in the abuses fairly consistently justified the "dirty war" as necessary for the achievement of superior goals.

An old question is whether we are justified in imposing through the criminal law our own values on people who not only do not share them but even lack the conceptual scheme which would make them capable of recognizing and

50. An example of this is the sanctions applied to South Africa for its apartheid policy such as economic sanctions, an oil embargo, and divestment. 
understanding our values. ${ }^{51}$ I have no doubt that our own mode of discourse is universalistic and unavoidably commits us to make judgments of intersubjective morality, even in relation to the conduct of people who do not share that mode of discourse..$^{52}$ It may be that, subjectively, a person's actions are excusable because he evaluates them through a distinct mode of discourse, i.e., he believes his actions were justified because his world view dictates the behavior in question. But this does not mean that a person's actions are objectively justified under the presuppositions of our mode of practical discourse. 53

However, when cleavages of different modes of discourse are established within the dominant one, and when the operation of the criminal law is not accompanied by a process of argumentation based on common ground, a serious threat to social stability and cohesion emerges. This happened to a certain extent with the trials for human rights violations in Argentina. The military maintained a high degree of solidarity during the trials, so much so that almost none of the soldiers would testify. They refused to recognize the trials as legitimate. Thus a situation emerged in which a powerful group did not accept the same norms and principles as the rest of society.

It is unlikely that the existence of a duty under international law selectively to prosecute past abuses of human rights would have contributed to bridging the gap between the unrelated modes of discourse. Perhaps some small but influential conservative sectors, which were inclined to justify the abuses, would have given in to the international pressure to go forward with the trials. But this probably would not have altered the outcome. The extremist sectors of the military almost certainly would not have been moved by international pressure to change their world view. On the contrary, pressure from the international community would have confirmed their belief that the military needed to protect Argentina from outside powers intent on weakening its sovereignty. And the inconsistency with which the superpowers righteously denounce smaller states for human rights violations would have been condemned by the relevant sectors of the military as hypocritical noise rather than as morally superior discourse.

\section{Maximalist Demands}

The communication between the government and human rights groups was not so much affected by differences in modes of discourse as by other factors.

51. This question has been repeatedly raised in Latin America in relation to homicides committed by indigenous people who thought that their victims either were bewitched or were going to bewitch innocent third parties. They justified their actions as self-defense. In one particular case, an Indian declared movingly before a court that if the judge believed in the devil he would not convict the defendents.

52. Even the possible judgment that we should tolerate the actions performed by people with different values and diverse justificatory schemes would commit us not to tolerate those actions which interfere with that tolerance.

53. See C. Nino, El Constructivismo Ético (1989). 
Many of the members of these groups have been extremely courageous during the repression. They included relatives of the victims who, of course, were deeply affected by the fate of their loved ones. But the emotional strains various groups suffered impaired their ability to be objective. The Mothers of Plaza de Mayo, for instance, insisted that the disappeared people should be made to appear alive, even when the unfortunate fact of their death was obvious to everybody. Consequently, the Mothers hindered investigations with actions such as opposing the inspection of anonymous tombs for the purpose of identifying the corpses.

An additional complication was that the human rights groups generally adopted an all-out retributive approach to the punishment of the acts of state terrorism that was not equally extended to the acts of left-wing terrorism. The groups accused the government of seeing things through "the theory of the two demons," which, to their minds, erroneously treated both terrorist groups as equally liable. The government replied that it intended, instead, to de-demonize Argentine politics by submitting everybody to the rule of law. But the groups remained committed to the exclusive goal of retribution of state terrorism. The retributivist view of punishment adopted by these organizations may have served to counterbalance any popular support for the general impunity of the military or the excessive pragmatism of some government officials who were inclined to adopt the easiest short-term solution. But once a certain threshold was passed, this retributive approach began to be harmful and self-frustrating.

First, the "all-or-nothing" attitude provided no incentive to promote the trials because, under the most extreme version, anything less than full prosecution of every last involved officer, which of course was impossible, was entirely without value. This attitude discouraged the government officials and adversely affected their willingness to promote and accelerate the critical prosecutions.

Both nationally and internationally, many people held extremely high expectations for the prosecutions without understanding the uncertainties Argentina faced in this experiment. There were people abroad who even suggested that Alfonsín's government had lost moral legitimacy because of the limitations put on the trials. Strangely enough, this conclusion coincided with that reached by the extremist sectors of the military, although derived from different premises. Second, the maximalist position of the human rights groups also served to confirm the fears of the opposition party that there was a plan to undermine the armed forces. The demand was formulated without discriminating among the military and instead by indicting the entire institution. Of course, this condemnation of the entire military did nothing to facilitate cooperation, even amongst those not remotely under threat of personal prosecution. Third, because the demands were extreme and indiscriminate, the human rights organizations arguably ended up discrediting themselves, along with the government, in the eyes of the general public. This outcome was very unfortunate, 
given the important role those organizations played in the past and might have to play in the future.

The incorporation into international law of a duty selectively to prosecute human rights abuses committed by a previous regime would have only fueled the maximalist demands, magnifying their divisive effect. The weakness of the retributive view of punishment on which the groups' demands were based would have been artificially propped up by positive international law, to the detriment of the cornered government. The incorporation would only de-legitimize and weaken even further a government which lacked the strength to comply with this duty, while not giving the government a bit of additional power for that compliance.

\section{Political Opportunism}

The opposition parties in Argentina cooperated in enacting many of the fundamental instruments for implementing President Alfonsín's policy on human rights. For instance, the nullification of the amnesty law was approved by all the parties represented in Congress. But there was also a relevant degree of opportunism, mainly when the difficulties of carrying forward the trials began to emerge. For example, the Peronist Party abstained from sending congressmen to the CONADEP, knowing that its lack of participation could affect the CONADEP's perceived legitimacy. And although Peronist legislators agreed in private about the need to limit the trials ${ }^{54}$ and provided a quorum in order to enact facilitating legislation, they publicly criticized the laws as concessions to the military.

This opportunism is not entirely due to defects in political virtue. Opportunism is also created by the dynamics of confrontation, which is inherent in a presidentialist system of government conjoined with strong and disciplined parties. $^{55}$

It is unlikely that opportunism would have been restrained by the existence of an international duty selectively to prosecute those who have violated human rights in the past. To the contrary, the opposition parties would have pointed out that the government was not complying with its international obligations, or even that it was a sort of pariah in the international community. The opposition parties-who did not absorb the political costs of limiting those trialswould have used the international attention to maximize their political gain. Only the prospect of extremely harsh sanctions could have forced the opposition parties to work seriously to go forward with the trials.

54. This is evidenced by their subsequent support of the much wider pardons granted by Menem.

55. See generally Nino, Transition to Democracy. Corporatism and Constitutional Reform in Latin America, 44 U. MIAMI L. REV. 129 (1989). 


\section{E. Double-talk}

Some degree of double-talk is inevitable in politics, given the self-satisfying and self-frustrating effects of predictions, threats, and warnings. For instance, many people insisted that when President Alfonsin sent to Congress the law of due obedience he should have been much more open about the risk to democracy and hence to future human rights. His personal credibility was harmed by the fact that he repeated the somewhat inconsistent statements that the law of due obedience was necessary for preserving the rule of law and that he was under no pressure whatsoever when deciding to promote it. It was important, though, that he did not over-emphasize the risk of military resistance for fear of exciting the military and of spreading a perception of weakness in the government. Thus, government officials were often accused of deliberately issuing different messages according to whether their audience were military officers, human rights groups, citizens, or international organizations. But if double-talk was common, this would have had several deleterious effects.

Consistent double-talk would have raised unrealistic expectations of the respective audiences which they would have then pressured the government to fulfill. And the inevitable failure of the government to meet all of these unrealistic expectations in turn would have created wide-spread frustration and dissatisfaction. And if the double-talk became known, it would have discredited the officials who spoke out of both sides of their mouths and would have generated the fears that they were conspiring with the opposite party.

If there had been an international duty selectively to prosecute past violations of human rights, with enforcement sanctions to provide support, perhaps the government would have been compelled to abandon any double-talk and would have openly confessed that it lacked the strength to punish these human rights abuses. This would have had some positive effects in lowering the expectations of different sectors of society and in generating some sympathy towards a government which was struggling between competing interests and values. But without enforcement sanctions, this open confession of weakness, as stated before, would have merely emasculated the image of the government, with unforeseeable results.

\section{CONCLUSION}

Given the circumstances, Alfonsín's investigation and prosecution of past human rights abuses held up miraculously well. The results, which were the product of uncoordinated actions of independent agents, were nearly all that could be morally required under the circumstances-a piece of what Bernard Williams calls "moral luck." ${ }^{, 66}$ The qualified success contributed to create a

56. B. Williams, MoRal LuCK passim. (1981). 
public consciousness about the horrors that are allowed when democracy and the rule of law are foregone. This consciousness is displayed by the fact that in the worst economic crisis of Argentina's history almost nobody supports an interference with the democratic process, unlike what happened in the past under milder economic pressures. It is also shown by the popular reactions against the pardons granted by President Menem.

These achievements of the government under President Alfonsín were produced without putting democratic institutions under an excessive strain from the reactions of the military. Consequently, the military is gradually changing its characteristic mode of discourse, accepting a less holistic view of the nation and a less elitist epistemic view about its needs. ${ }^{57}$

There have been few parallels in the world, certainly none in Latin America, of prosecuting those responsible for such atrocities. Furthermore, Argentina accomplished this without an invading army or a division of the armed forces backing the trials-literally with nothing other than moral appeal. But the main limitation put on Argentina's accomplishment under Alfonsín is due to public criticism. If people like Orentlicher think that the process was a partial failure then it was a partial failure. This is so because part of the success consists of subjective effects, such as the exemplary impact of the process on other developments, the pride of the citizens in the results of the trial, and the satisfaction of the victims.

The success, limited though it may be, was the product of a delicate equilibrium between many factors. I do not think that the equilibrium would have been fortified by the sort of international duty Orentlicher advocates. An international duty would perhaps have even further destabilized the process of promoting the trials. A legal duty selectively to prosecute human rights violations committed under a previous regime is too blunt an instrument to help successor governments who must struggle with the subtle complexities of re-establishing democracy.

Perhaps it would be much more helpful for international law to recognize the right of the world community to punish human rights violations in an international forum. The post-Nuremberg spirit of submitting perpetrators of crimes against human rights to international courts seems to be quite sensible. Violations of human rights belong with crimes such as terrorism, narcotics-trafficking, and destabilizing democratic governments, in a category of deeds which may, because of their magnitude, exceed the capacity of national courts to handle internally. Of course, it may be idealistic to hope for the establishment of such courts in the present state of international law; but it is no less realistic than to hope that the international community, through external political pressure, will enforce the duty to prosecute past human rights

57. This is shown, for instance, by the military's acceptance of a law of internal security which did not allow for its intervention in internal conflicts. 
abuses. But if the establishment of international courts seems impossible, intermediate solutions could be implemented, such as the internationalization of jurisdiction and the refusal of foreign courts to recognize amnesties, pardons, or special statutes of limitations for these kinds of crimes.

Second, an international duty could be extended to this kind of situation in a way which is more sensitive to the factual context than that proposed by Orentlicher. I refer to the duty of governments to safeguard human rights from future violation by the government or other parties. There are clear cases, condemned by present international law, in which governments violate human rights in a direct and active way. But there are also cases in which governments fail to preserve human rights in an indirect and passive way, by undermining the institutions, practices, cultural habits, and the economic structure which supports the preservation of human rights. These are not generally recognized as violations of that duty, although they should be. Sometimes a government's failure to investigate and to prosecute violations of human rights committed by a previous regime may justly be categorized as a passive abuse of human rights if it places those rights in future peril.

On occasion, though, what may appear to the international community to be passivity on the part of a government may actually be the active safeguarding against future violations at the cost of foregoing prosecution of past crimes. In other words, the factual context may frustrate a government's effort to promote the prosecution of persons responsible for human rights abuses, except at the risk of provoking further violence and a return to non-democratic rule. In such cases, the international community would assume responsibility for upholding the general duty I am proposing. This would be much more useful for the protection of human rights than the incorporation of an indiscriminate blunt duty to punish irrespective of the government's particular circumstances, especially the threat of future such violations.

With the international mechanism proposed here, foreign states and the international community would not be able to issue simplistic criticisms of a government's omission to prosecute a former regime's violations. Before reacting with criticisms and sanctions, the international community would have to undertake a thorough examination of the factual context and of the complex causal chains leading to the violation of human rights, which might be generated not only by lenience towards past abuses but also by other factors such as economic or political pressures. Such an examination could reveal that those obstacles originated in agents, such as outside governments, which are usually deemed to be above all suspicion.

In sum, Orentlicher's proposal, though wellintended and wellargued, would not aid a government attempting to prevent human rights violations in the future even when it decides to do so by prosecuting past abuses of human rights. What is needed, instead, is a system whereby the international community must consider the unique problems a particular successor democratic government 
faces and support the efforts that are needed to secure democracy and hence, human rights, for the future. The required knowledge of the factual circumstances of each case, in order to reach just and prudent solutions, excludes in general the epistemologically elitist attitude of direct intervention of outside powers; at the same time it allows for pressures ${ }^{58}$ which tend to provoke the people to discuss and decide for themselves the best way to protect their own rights. ${ }^{59}$

58. Like those carried out by the administration of President Carter, the Interamerican Commission on Human Rights, and others, while human rights were being violated in Argentina.

59. This connects with my defense of democracy, which should certainly be extended to the international sphere, based on its epistemic value for reaching correct (i.e., impartial) moral solutions for intersubjective conflicts. See C. NINO, THE ETHICS OF HUMAN RIGHTS (1991). 